\title{
INTERAKSI SIMBOLIS MASYARAKAT DALAM MEMAKNAI KESENIAN JATHILAN
}

\author{
Noor Haliemah dan Rama Kertamukti \\ Program Studi Ilmu Komunikasi UIN Sunan Kalijaga Yogyakarta, Jl. Marsda Adisucipto, \\ Caturtunggal, Kec. Depok, Kabupaten Sleman, Yogyakarta, No Hp. +62 8164223544 \\ Email: noorhaliemah@gmail.com, ramakerta@yahoo.com
}

\begin{abstract}
This research aims to explain how symbolic interaction of people in interpreting Jathilan art in Padukuhan Mendak Desa Girisekar. Kecamatan Panggang, Kabupaten Gunung Kidul. This research uses qualitative descriptive method. Data were collected using observation, in-depth interview and documentation. To check validity of data, the researcher uses triangulation of sources. The result shows that people interpret Jathilan art through verbal and non-verbal communication carried by Jathilan artists, within each performance or in everyday life. Verbal and non-verbal communication have been done by Jathilan artists through elements contained in Jathilan art including form of motion, costumes, properties and music. People can interpret Jathilan art because they regularly watch the show of Jathilan. In addition, the values contained in Jathilan art have been delivered to public through socialization as the first step so that values embodied in Jathilan art can be interpreted and implied by people in their life.
\end{abstract}

Keywords: Jathilan arts, symbolic interaction, symbol, padukuhan mendak gunung kidul

\begin{abstract}
Penelitian ini bertujuan untuk menjelaskan bagaimana interaksi simbolis masyarakat dalam memaknai kesenian jathilan. Penelitian ini menggunakan metode deskriptif kualitatif. Teknik pengambilan data menggunakan observasi, wawancara mendalam dan dokumentasi. Untuk melihat keabsahan data, peneliti menggunakan triangulasi sumber. Hasil dari penelitian ini menunjukkan bahwa masyarakat memaknai kesenian jathilan di Padukuhan Mendak Desa Girisekar. Kecamatan Panggang, Kabupaten Gunung Kidul melalui komunikasi verbal yang dilakukan oleh para pelaku kesenian jathilan, baik dalam setiap pementasan ataupun dalam kehidupan sehari-hari. komunikasi verbal yang dilakukan oleh para pelaku kesenian jathilan yaitu melaui unsur-unsur yang terdapat di dalam kesenian jathilan. Unsur-unsur tersebut meliputi bentuk gerak, kostum, properti dan iringan kesenian jathilan. Masyarakat dapat memaknai kesenian jathilan karena faktor terus-menerus menyaksikan pertunjukan jathilan. Selain itu, Nilai-nilai yang terkandung dalam aktivitas kesenian jathilan di Padukuhan Mendak mulai ditransformasIkan pada masyarakat melalui pengenalan (sosialisasi). Hal ini sebagai langkah awal agar nilai-nilai yang terkandung dalam aktivitas kesenian jathilan di Padukuhan Mendak tersebut dapat dimaknai dan diimplikasikan oleh warga Padukuhan Mendak dalam kehidupan bermasyarakat.
\end{abstract}

Kata kunci: kesenian jathilan, interaksi simbolik, simbol, padukuhan mendak gunung kidul

\section{Pendahuluan}

Yogyakarta sebagai representasi kota budaya di Indonesia masih melestarikan berbagai macam budaya yang berkembang di masyarakat, khususnya budaya jawa. Salah satu kesenian yang masih berkembang di masyarakat dan terus dilestarikan adalah kesenian Jathilan.
Daerah yang masih melestarikan kesenian tersebut adalah Padukuhan Mendak, Desa Girisekar. Desa Girisekar yang terletak di Kecamatan Panggang, Kabupaten Gunung Kidul merupakan desa yang kaya akan adat istiadat, kesenian dan kebudayaan. Di Padukuhan Mendak terdapat kelompok kesenian Jathilan bernama Sekar 
Manunggal Mudho. Kesenian Jathilan bagi masyarakat Padukuhan Mendak adalah salah satu aktivitas kemasyarakatan yang penuh dengan makna simbolik. Setiap individu tentunya memiliki identitasidentitas dalam karakter pribadinya. Bagi para pelaku kesenian Jathilan di Padukuhan Mendak, memungkinkan mereka untuk dapat berinteraksi baik antar anggota kelompok kesenian Jathilan maupun dengan masyarakat sekitar sehingga kelompok Jathilan tersebut masih bisa bertahan hingga kini dan hidup beriringan dengan masyarakat

Kesenian jathilan dikenal oleh masyarakat luas sebagai kesenian yang mengandung unsur magis atau supranatural. Hal tersebut tak jarang membuat orang-orang memiliki pemaknaan yang berbeda-beda terhadap kesenian tersebut. Kesenian Jathilan kini juga telah mengalami perubahan demi tuntutan kebutuhan pasar. Menurut Drs. Kuswarsantyo, M.Hum dalam disertasinya berjudul "Perkembangan Kesenian Jathilan Di Daerah Istimewa Yogyakarta Dalam Era Industri Pariwisata (1986-2013)" yang dikutip dari ugm.ac.id menyebutkan bahwa permasalahan dalam kesenian Jathilan muncul terkait upaya memakasakan kehendak demi untuk menuruti kebutuhan pasar yang sesungguhnya tidak sesuai dengan esensi kesenian Jathilan.

Kesenian Jathilan selalu identik dengan trance, atraksi yang mengerikan dan mabuk. Masyarakat juga menganggap Jathilan sebagai sarana hiburan semata, padahal ada makna-makna lain dari kesenian Jathilan yang belum banyak masyarakat yang mengetahuinya. Dalam proses pertunjukan kesenian Jathilan berlangsung pula proses interaksi simbolik antara pemain dan pemain atau masyarakat sekitar yaitu adanya proses penyampaian pesan melalui simbol-simbol tertentu antara pemain dan penonton. Teori interaksi simbolis mengajarkan bahwa makna muncul sebagai hasil interaksi antara manusia baik secara verbal maupun nonverbal. Melalui aksi dan respons yang terjadi, kita memberikan makna ke dalam kata-kata atau tindakan, dan karenanya kita dapat memahami suatu peristiwa dengan cara cara tertentu (Morissan, 2013: 110). Menurut Soekanto (1982: 8), teori interaksi simbolis berasumsi bahwa dasar dari kehidupan bersama dari manusia adalah komunikasi, terutama lambang-lambang yang merupakan kunci untuk memahami kehidupan sosial manusia. Suatu lambang merupakan tanda, benda atau gerakan yang secara sosial dianggap mempunyai arti-arti tertentu.

Penelitian ini menggunakan unit analisis yaitu aspek-aspek interaksi simbolik yang diusung oleh George Herbert Mead, mengungkapkan bahwa aspek-aspek interaksi simbolik menurut Mead melalui Tindakan, Gesture (Gerak Isyarat), Simbol Signifikan, Mind (Pikiran), Self(Diri), Society (Masyarakat) (Ritzer, 2012: 603-604). Dedy Mulyana mengemukakan teori interaksi simbolik adalah "Kehidupan sosial pada dasarnya adalah interaksi manusia dengan menggunakan simbol-simbol. Mereka tertarik pada cara manusia menggunakan simbolsimbol yang mempresentasikan apa yang mereka maksudkan untuk berkomunikasi dengan sesamanya dan juga pengaruh yang ditimbulkan penafsiran atas simbol-simbol ini terhadap perilaku pihak-pihak yang terlibat 
dalam interaksi sosial" Secara ringkas interaksi simbolik didasarkan pada premis-premis berikut: 1) Individu merespon suatu situasi simbolik. Mereka merespon lingkungan, termasuk objek fisik (benda) dan objek sosial (perilaku manusia) berdasarkan makna yang dikandung komponen-komponen lingkungan tersebut bagi mereka. Respon yang diberikan saat menghadapi situasi tersebut tidak bersifat mekanis, tidak pula ditentukan oleh faktorfaktor eksternal. Respon mereka bergantung pada bagaimana mereka mendefinisikan situasi yang dihadapi dalam interaksi sosial. Jadi individulah yang dipandang aktif untuk menentukan lingkungan mereka sendiri. 2) Makna adalah produk interaksi sosial, karena itu makna tidak melekat pada objek, melainkan dinegosiasikan melalui penggunaan bahasa. Negosiasi itu dimungkinkan karena manusia mampu menamai segala sesuatu, bukan hanya objek fisik, tindakan atau peristiwa (bahkan tanpa kehadiran objek fisik, tindakan atau peristiwa itu), namun juga gagasan yang abstrak. 3) Makna yang diinterpretasikan individu dapat berubah dari waktu ke waktu, sejalan dengan perubahan situasi yang ditemukan dalam interaksi sosial. Perubahan interpretasi dimungkinkan karena individu dapat melakukan proses mental, yakni berkomunikasi dengan dirinya sendiri. Manusia membayangkan atau merencanakan apa yang akan mereka lakukaan. (Mulyana, 2008: 71).

Keunikan dan dinamika simbol dalam proses interaksi sosial menuntut manusia harus lebih kritis, peka, aktif dan kreatif dalam menginterpretasikan simbol-simbol yang muncul dalam interaksi sosial, penafsiran yang tepat atas simbol tersebut turut menentukan arah perkembangan manusia dan lingkungan, sebaliknya, penafsiran yang keliru atas simbol dapat menjadi petaka bagi hidup manusia dan lingkungannya. Esensi interaksi simbolik adalah suatu aktifitas yang merupakan ciri khas manusia, yakni komunikasi dan pertukaran simbol yang diberi makna (Mulyana, 2008: 68). Interaksi simbolik berusaha memahami perilaku manusia dari sudut pandang subjek. Interaksi simbolik ini menyarankan bahwa perilaku manusia harus dilihat sebagai proses yang memungkinkan membentuk dan mengatur perilaku mereka dengan mempertimbangkan ekspektasi orang lain yang menjadi mitra mitra interaksi mereka. Keunikan dan dinamika simbol dalam proses interaksi sosial menuntut manusia harus lebih kritis, peka, aktif dan kreatif dalam menginterpretasiikan simbol-simbol yang muncul dalam interaksi sosial. Penafsiran yang tepat atas simbol tersebut turut menentukan arah perkembangan manusia dan lingkungan. Sebaliknya, penafsiran yang keliru atas simbol dapat menjadi petaka bagi hidup manusia dan lingkungannya.

Peneliti tertarik meneliti bagaimana masyarakat Padukuhan Mendak, Desa Girisekar, Kecamatan Panggang, Kabupaten Gunung Kidul memaknai kesenian jathilan yang tumbuh dan berkembang di daerah tersebut. Teori interaksi simbolis mengajarkan bahwa makna muncul sebagai hasil interaksi diantara manusia baik secara verbal maupun nonverbal. Melalui aksi dan respons yang terjadi, kita memberikan makna ke dalam kata-kata atau tindakan, dan karenanya kita dapat memahami 
suatu peristiwa dengan cara cara tertentu (Morissan, 2013: 110). Menurut Soekanto (1982: 8), teori interaksi simbolis berasumsi bahwa dasar dari kehidupan bersama dari manusia adalah komunikasi, terutama lambang-lambang yang merupakan kunci untuk memahami kehidupan sosial manusia. Suatu lambang merupakan tanda, benda atau gerakan yang secara sosial dianggap mempunyai arti-arti tertentu.

\section{Metode Penelitian}

Jenis penelitian ini adalah penelitian kualitatif, yaitu penelitian yang memiliki hasil deskripsi berupa kata dan tulisan dari informan. Pendekatan yang digunakan adalah pendekatan deskriptif dimana peneliti mencari fakta, fenomena tentang interaksi simbolis pelaku kesenian, baik interaksi dengan sesama anggota kelompok maupun interaksi dengan masyarakat sekitar dalam kehidupan sehari-hari.

Subjek penelitian dalam penelitian ini adalah beberapa warga Padukuhan Mendak, Desa Girisekar, Kecamatan Panggang, Kabupaten Gunung Kidul. Narasumber yang dipilih adalah mereka yang dianggap dapat memberikan informasi terkait permasalahan penelitian. Pada penelitian ini yang menjadi objek penelitian adalah interaksi simbolis masyarakat dalam memaknai kesenian Jathilan pada Kelompok Jathilan Sekar Manunggal Mudho, Padukuhan Mendak, Desa Girisekar, Kecamatan Panggang, Kabupaten Gunung Kidul.

Teknik pengumpulan data dalam penelitian ini menggunakan wawancara mendalam, observasi dan dokumentasi. Teknik analisa data yang digunakan dalam penelitian ini mengacu pada analisa Miles dan Huberman yaitu (dalam Sugiyono, 2014: 246), Miles dan Huberman mengungkapkanbahwa aktivitas dalam analisis data yaitu data reduction, data display, dan conclusion drawing/verification. Pemeriksaan keabsahan data dalam penelitian ini menggunakan triangulasi sumber.

\section{Hasil Penelitian dan Pembahasan}

Penelitian ini diilhami pada penelitian sebelumnya mengenai Interaksi Simbolik yang diteliti oleh Eny Kusumastuti, Staf Pengajar Jurusan Sendratasik FBS UNNES tahun 2006, tentang Laesan Sebuah Fenomena Kesenian Pesisir: Kajian Interaksi Simbolik Antara Pemain Dan Penonton. Ia memberikan banyak fakta mengenai interaksi simbolik yang dihadirkan dalam penelitiannya; bagaimana proses terjadinya interaksi simbolik antara pelaku kesenian Laesan dengan penonton dan simbol-simbol apakah yang dapat membentuk terjadinya proses interaksi simbolik antara pelaku kesenian Laesan dengan penonton. Hasil penelitian menunjukkan bahwa proses interaksi simbolik terjadi pada setiap bagian pertunjukan dan simbol-simbol yang membentuk proses interaksi simbolik meliputi dupa, sesaji, nyanyian pengiring, makna trance dalam Laesan.

Begitu pula obyek yang saya teliti mengenai Jathilan, sebagai salah satu dari sekian banyak jenis kesenian tradisional yang ada di wilayah Daerah Istimewa Yogyakarta (DIY). Penampilan kesenian Jathilan menggunakan properti kuda képang. Pertunjukan Jathilan ditampilkan dengan mengambil cerita roman Panji. Namun dalam perkembangannya, kini Jathilan tidak hanya bertumpu pada cerita roman Panji, 
tetapi dapat pula mengambil setting cerita wayang (Mahabarata atau Ramayana) dan legenda rakyat setempat. Kuswarsantyo dalam penelitian berjudul "Seni Jathilan: Bentuk, Fungsi Dan Perkembangannya (1986-2013:2)”, mengemukakan bahwa. Kesenian Jathilan mempunyai fungsi : (1) ritual sakral dalam upacara bersih desa; (2) pertunjukan; (3) hiburan. Mencermati kata ritual itu akan terbayang adanya suasana magis dalam pelaksanaan kesenian itu. Kesenian Jathilan merupakan bagian dari kesenian yang sejak dulu digunakan sebagai sarana untuk melibatkan masyarakat secara langsung dalam pertunjukan. Jathilan memang menggambarkan sitausi prajurit yang tengah berperang naik kuda dan bersenjatakan pedang.

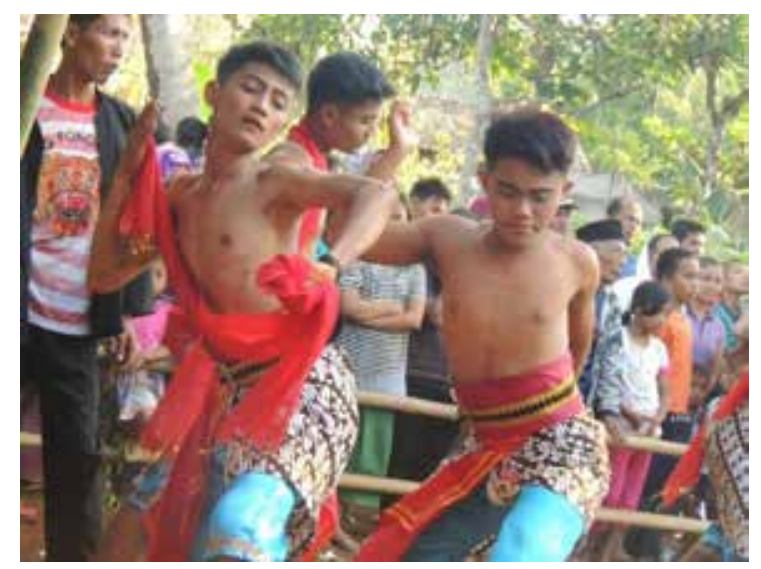

Gambar 1. Pemain Jathilan Putra saat Melakukan Pertunjukan

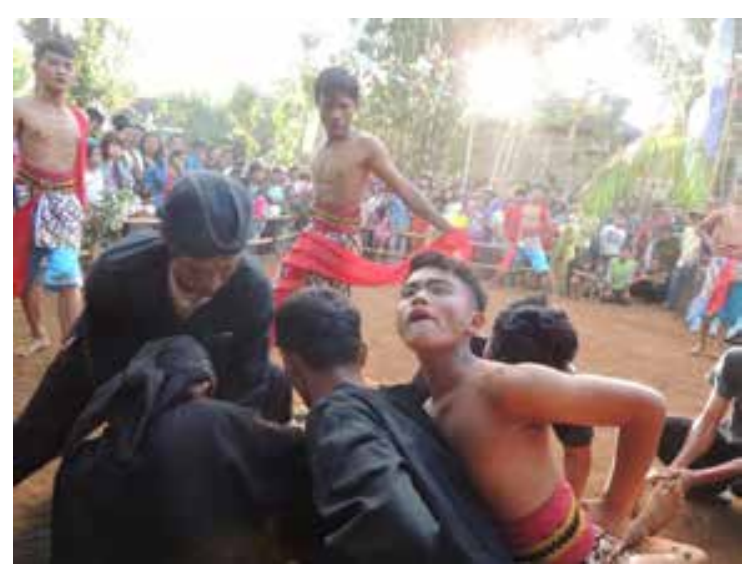

Gambar 2. Adegan Ndadi Atau Kerasukan Roh Halus
Pada awalnya tari ini hanya dibawakan dua orang secara berpasangan. Interaksionisme simbolik berasumsi bahwa dasar dari kehidupan bersama dari manusia adalah komunikasi, terutama lambanglambang yang merupakan kunci untuk memahami kehidupan sosial manusia. Suatu lambang merupakan tanda, benda atau gerakan yang secara sosial dianggap mempunyai arti-arti tertentu (Soekanto, 1982: 8). Dalam bab ini akan disajikan data dan sekaligus analisanya mengenai interaksi simbolis masyarakat dalam memaknai kesenian Jathilan pada kelompok Jathilan Sekar Manunggal Mudho, Padukuhan Mendak, Desa Girisekar, Kecamatan Panggang, Kabupaten Gunung Kidul. Informan dalam penelitian ini adalah warga Padukuhan Mendak yang dipilih berdasarkan keanggotaan dalam kelompok Jathilan Sekar Manunggal Mudho dan status sosial dalam masyarakat. Informan yang dianggap dapat memberikan informasi terkait permasalahan penelitian diantaranya adalah tokoh masyarakat, tokoh seni budaya setempat dan anggota kelompok Jathilan Sekar Manunggal Mudho.

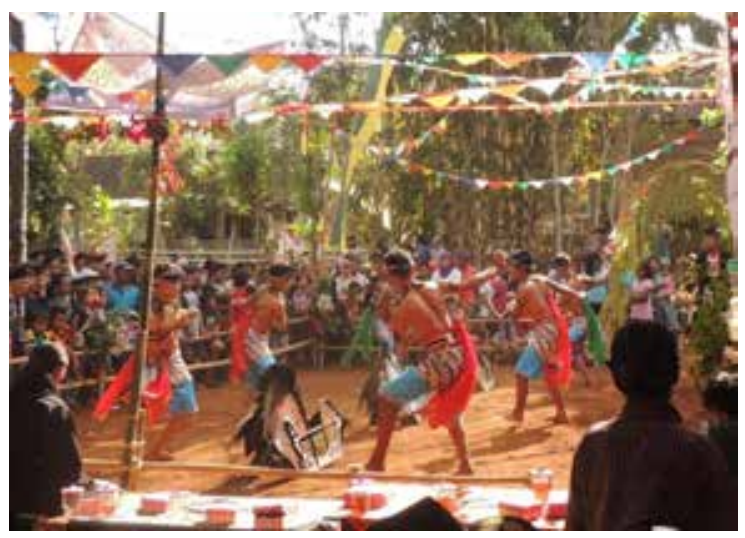

Gambar 3. Gelar Budaya Kayubalung 


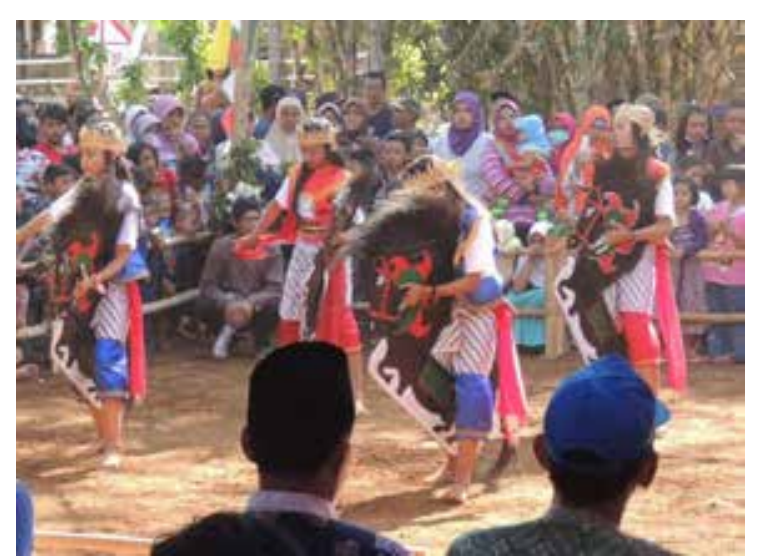

Gambar 4. Pemain Jathilan Putri Ketika Melakukan Pertunjukan

Sumber: Dokumentasi Peneliti

\section{Aspek Interaksi Simbolis Masyarakat Dalam Memaknai Kesenian Jathilan}

Interaksi simbolik ini menunjuk kepada sifat khas dari interaksi antar manusia. Kekhasannya adalah manusia saling menerjemahkan dan saling mendefinisikan tindakannya. Bukan hanya reaksi belaka dari tindakan orang lain, tapi didasarkan atas "makna" yang diberikan terhadap tindakan orang lain. Interaksi antar individu, diantarai oleh penggunaan simbol-simbol, interpretasi atau dengan saling berusaha untuk saling memahami maksud dari tindakan masing-masing. Dalam interaksionisme simbolis, seseorang memberikan informasi hasil dari pemaknaan simbol dari perspektifnya kepada orang lain dan si penerima informasi tersebut akan memiliki perspektif lain dalam memaknai informasi yang disampaikan aktor pertama. Dapat dikatakan bahwa aktor akan terlibat dalam proses saling mempengaruhi sebuah tindakan sosial. Untuk dapat melihat adanya interaksi sosial yaitu dengan melihat individu berkomunikasi dengan komunitasnya dan akan mengeluarkan bahasa-bahasa, kebiasaan atau simbol-simbol baru yang menjadi objek penelitian. Seperti yang diungkapkan oleh
Mead bahwa aspek-aspek interaksi simbolik melalui Tindakan, Gesture (Gerak Isyarat), Simbol Signifikan, Mind (Pikiran), Self (Diri), Society (Masyarakat) (Ritzer, 2012: 603-604).

\section{Tindakan}

Hasil dari penelitian ini diperlihatkan bahwa perbuatan manusia dilakukan karena generalisasi disposisi untuk bertindak. Tindakan itu muncul karena ada desakan yang kuat dari dalam (dorongan hati) yang dialami atau yang dirasakan manusia. Seperti yang dialami para pelaku kesenian Jathilan bahwa keinginan mereka bergabung dalam kelompok kesenian Jathilan memang berasal dari dorongan hati dan keinginan mereka sendiri, meskipun sudah mengetahui konsekuensi-konsekuensi yang harus ditanggung dan seperti apa tanggung jawab ketika telah bergabung dengan kelompok Jathilan Sekar Manunggal Mudho.

Tahap dasar dan saling berhubungan di dalam tindakan, yaitu impuls (dorongan hati), perception (persepsi), manipulation (manipulasi), consummation (penyelesaian). Menurut Mead, perbuatan manusia dilakukan karena generalisasi disposisi untuk bertindak. Tindakan itu muncul karena ada desakan yang kuat dari dalam impuls (dorongan hati) yang dialami atau yang dirasakan manusia. Seperti yang dialami para pelaku kesenian Jathilan bahwa keinginan mereka bergabung dalam kelompok kesenian Jathilan memang berasal dari dorongan hati dan keinginan mereka sendiri, meskipun sudah mengetahui konsekuensi-konsekuensi yang harus ditanggung dan seperti apa tanggung jawab ketika telah bergabung dengan kelompok Jathilan Sekar Manunggal Mudho. Kemudian 
Tahap selanjutnya yaitu persepsi. Pada tahap ini seorang individu mengartikan situasi yang mereka hadapi ke arah gerak organisme manusia. Pada dasarnya manusia diarahkan untuk mencari atau mencapai suatu objek, manusia dan peristiwa. Persepsi itu pada mulanya merupakan respon indrawi terhadap stimulus luar. Terdapat adegan dalam kesenian Jathilan yang masih menjadi pro dan kontra di masyarakat, yaitu adegan ndadi. Persepsi masyarakat terhadap adegan yang menjadi ciri kas kesenian Jathilan tersebut berbeda-beda.

Tahap selanjutnya manipulasi. Manusia memanipulasi lingkungan mereka, berbuat di dalamnya, menanganinya, lalu tiba pada kontak tertentu dengan aspek-aspek yang relevan. Melalui manipulasi manusia berusaha memakai objek untuk diarahkan kepada tujuan yang telah diberi arti tertentu. Seperti yang telah disebutkan sebelumnya bahwa masih terdapat pro dan kontra mengenai adegan ndadi dalam kesenian Jathilan, hingga beberapa penari Jathilan mengalami masalah yang sama yaitu sulitnya mendapat ijin orangtua. Tahapan consummation (penyelesaian), para aktor di lingkungan kesenian Jathilan memberikan penilaian negative positifnya anggota keluarga turut dalam berkesenian.

Terdapat adegan yang masih menjadi pro dan kontra di masyarakat, yaitu adegan ndadi. Persepsi masyarakat terhadap adegan yang menjadi ciri kas kesenian Jathilan tersebut berbeda-beda. Setiap pertunjukan kesenian Jathilan, terdapat rangkaian prosesi dari sebelum pertunjukan dimulai hingga pertunjukan selesai. Masyarakat yang kesehariannya berinteraksi langsung dengan pelaku kesenian Jathilan dan selalu mengikuti pertunjukan Jathilan, sebagian besar mengetahui prosesi apa saja yang dilakukan oleh sebuah kelompok Jathilan.

Rangkaian prosesi dalam pertunjukan Jathilan yaitu: 1) Tata rias untuk penari Jathilan putra dan putri. 2) Pawang Jathilan memanjatkan doa-doa agar penari Jathilan putri tidak mengalami kerasukan. 3) Ritual pemanggilan roh halus untuk masuk ke dalam properti kuda. 4) Pertunjukan Jathilan putri lalu dilanjutkan pertunjukan Jathilan putra 5) Puncak pertunjukan kesenian Jathilan, yaitu penari Jathilan putra ndadi atau kerasukan roh halus. 6) Ritual mengeluarkan roh halus dari tubuh penari Jathilan putra.

Hasil penelitian menunjukkan bahwa masyarakat mendapat pemahaman baru mengenai unsur-unsur yang ada dalam kesenian Jathilan karena sering menyaksikan pertunjukan Jathilan dan sering bertukar pikiran dengan anggota kelompok Jathilan Sekar Manunggal Mudho. Dapat disimpulkan bahwa masyarakat mempelajari maknamakna tersebut melalui interaksi dengan para pelaku kesenian Jathilan.

\section{Gesture (Gerak Isyarat)}

Herbert Mead mendefinisikan gerak isyarat (gesture) adalah gerakan-gerakan dari organisme pertama yang bertindak sebagai stimuli spesifik yang membangkitkan (secara sosial) respons-respons yang tepat pada organisme kedua. Masyarakat Padukuhan Mendak memaknai adegan-adegan dalam kesenian Jathilan melalui gerakan-gerakan yang dilakukan oleh pelaku kesenian Jathilan. Dalam setiap pertunjukan kelompok 
Jathilan Sekar Manunggal Mudho, selalu diawali dengan masuknya pawang ke arena pertunjukan lalu menebarkan bunga sembari membaca doa-doa.

Masyarakat Padukuhan Mendak memaknai adegan-adegan dalam kesenian Jathilan melalui gerakan-gerakan yang dilakukan oleh pelaku kesenian Jathilan. Puncak pertunjukan Jathilan adalah adegan ndadi yang mempertontonkan atraksiatraksi ekstrim. Adegan ndadi ini dimulai dengan tanda pawang membakar kemenyan, lalu pemain Jathilan putra melangkahi properti kudanya. Gerakan pawang membakar kemenyan dan pemain Jathilan putra melangkahi kudanya tersebut menjadi simbol yang dimaknai oleh para penonton Jathilan sebagai tanda bahwa pemain Jathilan akan segera ndadi.

Masyarakat dapat memaknai adegan ndadi dalam pertunjukan Jathilan melalui gerakan-gerakan yang dilakukan pemain Jathilan di panggung. Masyarakat telah memahami makna-makna setiap adegan dalam kesenian Jathilan melalui gesture atau gerak tubuh yang ditunjukan pelaku kesenian Jathilan selama pertunjukan. Gerak tubuh tersebut contohnya gerakan pemain Jathilan yang minta untuk dimandikan, minta selendang untuk penutup kepala, dan minta dibungkus kain. Masyarakat dapat memaknai itu semua karena pengalaman secara terus menerus menyaksikan pertunjukan Jathilan.

Kesenian Jathilan merupakan kesenian yang identik dengan properti kuda. Baik Jathilan putra maupun putri, keduanya menggunakan kuda saatmenari. Perbedaannya terlihat ketika ritual menjelang pertunjukan Jathilan yaitu sebelum tampil, pawang melakukan ritual do'a untuk membetengi pemain Jathilan putri agar tidak ndadi atau kerasukan, sedangkan ritual untuk Jathilan putra adalah memanggil roh halus untuk masuk ke dalam properti kuda. Masyarakat memaknai hal tersebut bahwa pemain Jathilan putra kerasukan roh halus dan mengerti ini berupa kesenian.

\section{Simbol Signifikan}

Mead menyebut simbol signifikan sebagai simbol yang maknanya secara umum disepakati oleh orang banyak. Makna simbol penting dalam komunikasi bagi seseorang dan bagi orang lain. Seseorang menggunakan lambang atau simbol untuk memberikan pengertian kepada orang lain. Manusia hidup dalam suatu lingkungan simbol-simbol. Manusia memberikan tanggapan simbolsimbol itu seperti juga ia memberikan tanggapan terhadap rangsangan yang bersifat fisik. Pengertian dan penghayatan terhadap simbol-simbol yang tak terhitung jumlah itu merupakan hasil pelajaran dalam pergaulan hidup bermasyarakat. Simbol mengacu pada setiap objek sosial (misalnya benda fisik, isyarat, atau kata).

Kesenian Jathilan merupakan aktivitas kemasyarakatan di Padukuhan Mendak yang penuh dengan makna simbolik. Unsur-unsur yang terkandung didalamnya seperti gerakan, tata rias, properti, kostum dan iringan lagu merupakan simbol-simbol yang ada pada kesenian Jathilan.

Adegan ndadi dalam kesenian Jathilan tidak lepas dari unsur sesajen di dalamnya. Sesajen yang harus ada di setiap pertunjukan 
Jathilan meliputi kembang kanthil, menyan, pisang dan mongmong atau nasi liwet. makna sesajen dalam kesenian Jathilan adalah untuk meminta keselamatan. Masyarakat dapat memaknai keseluruhan sesajen tersebut berdasarkan falsafah jawa. Sesajen tersebut sebagai syarat untuk mendatangkan roh halus yang akan berperan dalam adegan ndadi pada kesenian Jathilan. Sesajen tersebut untuk melindungi dari gangguan roh halus dan agar keseluruhan pemain Jathilan, penonton, dan warga yang berada di lokasi pertunjukan Jathilan diberi keselamatan.

Kostum untuk pemain Jathilan putra menunjukkan busana seorang prajurit kerajaan. Untuk mendukung gambaran prajurit dalam pertunjukan Jathilan, para pemain menggunakan tata rias yang menonjolkan peran-peran mereka. Unsur lain yaitu lagu-lagu yang mengiringi kesenian jathilan. Lagu-lagu yang mengiringi pertunjukan Jathilan membawa pesan positif dan berisi ajakan melakukan kebaikan. Lagu-lagu yang dibawakan sinden untuk mengiringi pertunjukan kesenian Jathilan dimaknai positif oleh masyarakat. Masyarakat dapat memahami isi lagu tersebut melalui simbol kata yaitu syair lagu tersebut.

Kuda yang merupakan properti dalam kesenian Jathilan memiliki simbol warna. Simbol warna pada properti kuda yang digunakan dalam setiap pertunjukan Jathilan ternyata memiliki arti masingmasing yaitu warna putih menyimbolkan kebaikan, warna merah menyimbolkan keberanian dan warna hitam menyimbolkan keserakahan.

\section{Mind (Pikiran)}

Pada awalnya sebagian besar kesenian tradisional berfungsi untuk upacara adat atau ritual. Masyarakat percaya jika kesenian tersebut tidak dipersembahkan dalam upacara adat maka akan menimbulkan bencana. Fungsi hiburan lebih mendominasi aktivitas kesenian tersebut. Kesenian Jathilan kini juga telah mengalami perubahan demi tuntutan kebutuhan pasar hingga masyarakat menganggap Jathilan sebagai sarana hiburan semata. Masyarakat umum menganggap Jathilan dulu dan sekarang berbeda. Jathilan dulu adalah Jathilan klasik yang tidak ada iringan lain selain kendang, sedangkan Jathilan yang dianut kelompok Jathilan Sekar manunggal Mudho sekarang adalah Jathilan modern yang penuh dengan kreasi baru mulai dari lagu-lagu iringan, gerakan dan adegan-adegan. Setiap pertunjukan yang dilakukan oleh kelompok jathilan Sekar Manunggal Mudho, masyarakat yang datang tidak hanya dari daerah Padukuhan Mendak, namun banyak penonton dari luar daerah berbondong-bondong datang untuk menyaksikan pertunjukan Jathilan. Hal tersebut menggambarkan bahwa kesenian Jathilan disajikan sebagai hiburan masyarakat, bukan untuk ritual tertentu.

Para warga Padukuhan Mendak juga mendukung sepenuhnya dengan adanya kelompok Jathilan di dusun mereka. Masyarakat beranggapan bahwa adanya kesenian Jathilan di Padukuhan Mendak membawa dampak positif untuk masyarakat. Kelompok Jathilan ini menjadi kegiatan positif dan menjadi hiburan untuk masyarakat. 
Mengenai kehadiran kesenian Jathilan ditengah tengah masyarakat, masing-masing individu memiliki penafsiran yang berbedabeda. Penafsiran masyarakat tersebut bergantung pada kondisi dan latar belakang masing-masing individu. Seperti yang telah diungkapkan sebelumnya bahwa masyarakat mengembangkan pikiran melalui interaksi dengan orang lain, dalam hal ini interaksi yang terjadi yaitu antara masyarakat dengan pelaku kesenian Jathilan.

\section{Self (Diri)}

Peneliti menganalisis para pelaku kesenian Jathilan ketika memposisikan dirinya pada posisi sebagai "I" atau subjek atau diri yang bertindak. Para pelaku kesenian jathilan sebenarnya mengetahui bahwa adegan ndadi mengandung unsur magis dan dapat membahayakan diri, namun para pelaku kesenian Jathilan telah menerima segala konsekuensi bergabung dalam sebuah kelompok Jathilan, walaupun mendapat tentangan dari pihak keluarga ataupun lingkungan sekitar. Mead mendefinisikan diri (self) sebagai kemampuan untuk merefleksikan diri kita sendiri dari perspektif orang lain. Ketika Mead berteori mengenai diri, ia mengamati bahwa manusia mempunyai kemampuan untuk menjadi subjek dan objek bagi dirinya sendiri. Mead menyebut subjek atau diri yang bertindak sebagai "I", sedangkan objek atau diri yang mengamati adalah "Me".

Para pelaku kesenian Jathilan dapat berbaur dengan masyarakat bahkan seperti tidak ada perbedaan karena memang sesungguhnya para pelaku kesenian Jathilan yang bergabung dalam kelompok Jathilan Sekar Manunggal Mudho adalah termasuk anggota masyarakat juga. Dalam hal ini, pelaku kesenian Jathilan memposisikan diri sebagai "Me" dimana mereka layaknya masyarakat biasa dan dapat hidup berdampingan mengikuti segala kegiatan kemasyarakatan. Pelaku kesesenian Jathilan yang berada di posisi " $m e$ " ini dapat menjaga hubungan baik, terutama para pemuda yang menjadi penari Jathilan tetap menjaga sopan santun ketika berada di tengah-tengah masyarakat. Peneliti berpendapat bahwa nilai-nilai positif yang terkandung dalam unsurunsur kesenian Jathilan dapat membentuk karakter anak-anak dan pemuda-pemuda di Padukuhan Mendak. Berdasarkan observasi peneliti, anak-anak dan pemuda-pemudi di Padukuhan Mendak sangat menghormati orang yang lebih tua dan bersikap sopan kepada semua orang. Mereka masih menjaga penggunaan bahasa krama halus saat berkomunikasi dengan orangtua.

\section{Society (Masyarakat)}

Kelompok Jathilan di Padukuhan Mendak dapat berkembang dan semakin dikenal di daerah lain karena beberapa faktor, yaitu adanya dukungan masyarakat dan pihak keluarga. Keinginan para pelaku kesenian jathilan untuk bergabung di kelompok Jathilan Sekar Manunggal Mudho juga datang dari diri sendiri. Dalam hal ini yang mengambil posisi particular other adalah anggota keluarga dari para pelaku kesenian Jathilan dan teman sesama anggota kelompok Jathilan Sekar Manunggal Mudho. Mead berargumen bahwa interaksi mengambil tempat di dalam sebuah struktur sosial yang dinamis - budaya, masyarakat, dan 
sebagainya. Mead mendefinisikan masyarakat (society) sebagai jejaring hubungan sosial yang diciptakan manusia. Individu-individu terlibat di dalam masyarakat melalui perilaku yang mereka pilih secara aktif dan sukarela. Masyarakat terdiri atas individu-individu dan Mead berbicara mengenai dua bagian penting masyarakat yang mempengaruhi pikiran dan diri. Pemikiran Mead mengenai oranglain secara khusus (Particular Other) merujuk pada indiviu- individu dalam masyarakat yang signifikan bagi kita. Sedangkan orang lain secara umum (Generalized Other) merujuk pada cara pandang dari sebuah kelompok sosial atau budaya sebagai suatu keseluruhan.

Berdirinya kelompok Jathilan Sekar Manunggal Mudho tidak lepas dari andil warga masyarakat Padukuhan Mendak dan dorongan dari pihak internal para pelaku kesenian Jathilan. Selain masyarakat yang mendukung, para pelaku kesenian Jathilan juga mendapat dukungan dari pihak keluarga. Terlihat bahwa kelompok Jathilan Sekar Manunggal Mudho membangun komunikasi yang baik dengan lingkungan sekitar. Minto selaku ketua kelompok Jathilan menggandeng warga masyarakat dan pihak keluarga dari pemuda-pemudi yang berkeinginan untuk bergabung ke dalam kelompok Jathilan.

Pembentukan kelompok Jathilan Sekar Manunggal Mudho juga mengikutsertakan warga masyarakat dan pihak keluarga dalam musyawarah. Dalam musyawarah tersebut, ketua kelompok memberitahukan konsekuensi-konsekuensi yang akan dihadapi para pelaku kesenian Jathilan termasuk adanya adegan ndadi untuk
Jathilan putra. Hal ini mewakili poin sosialisasi dalam aspek interaksi simbolik. Selain melakukan sosialisasi dengan keluarga para pelaku kesenian Jathilan, pawang juga menjelaskan prosesi-prosesi dalam kesenian Jathilan pada penari Jathilan. Dari penelitian peneliti, diketahui bahwa para pelaku kesenian Jathilan memahami makna-makna setiap adegan dalam kesenian Jathilan melalui sosialisasi dari pawang Jathilan.

Dalam kesenian Jathilan, adanya adegan ndadi masih menjadi perdebatan. Terdapat masyarakat yang pro dan kontra menanggapi adegan ndadi yang terkesan ekstrim dan magis. Masyarakat memiliki pendapat yang berbedabeda dalam memaknai rangkaian adegan $n d a d i$ yang melibatkan roh halus dalam prosesinya. Adanya kelompok Jathilan Sekar Manunggal Mudho di Padukuhan Mendak menjadi wadah untuk warga masyarakat menyalurkan bakat seninya. Selain itu, adanya kesenian Jathilan di tengah-tengah masyarakat menjadi pemersatu antara RT 12 dan RT 13 Padukuhan Mendak, yang sebelumnya jika ada kegiatan selalu berjalan sendiri-sendiri.

Selain itu, setelah kelompok Jathilan ini berdiri di tengah-tengah masyarakat, terlihat perubahan besar di daerah Kayubalung (RT 12 dan RT 13), Padukuhan Mendak. Daerah Kayubalung yang dulunya dikenal dengan dusun terpencil, tidak berkembang dan sering diremehkan, sekarang semakin maju, namanya berkibar dan bisa menjadi contoh untuk daerah lain. Selain banyak yang mendukung adanya kelompok kesenian jathilan di tengah-tengah masyarakat Padukuhan Mendak, namun ada juga 
kelompok masyarakat yang kontra terhadap kesenian Jathilan. Namun hal tersebut tidak menyebabkan perpecahan diantara warga. Warga masyarakat Padukuhan Mendak selalu mengutamakan sikap saling menghargai. Terlebih dengan adanya kesenian di tengah-tengah masyarakat bisa menambah keguyub-rukunan warga, karena sesungguhnya pelaku kesenian juga termasuk anggota masyarakat.

Kelompok Jathilan Sekar Manunggal Mudho mengutamakan kelompok pemuda untuk mengisi bagian penari dengan tujuan untuk mendidik generasi penerus, mengenalkannya pada kesenian yang merupakan warisan bangsa, agar nantinya kesenian tersebut bisa terus lestari dan tidak punah di telan jaman.

Salah satu cara menjaga kesenian Jathilan yang ada di Padukuhan Mendak paling penting adalah menjaga latihan rutin bersama masingmasing anggota kelompok kesenian tersebut. Latihan rutin dimaksudkan agar satu sama lain anggota kesenian dapat saling memahami dan mengerti dalam interaksi yang terjalin. Latihan rutin menjadi wadah bertemunya para anggota kelompok Jathilan Sekar Manunggal Mudho untuk dapat berbagi ilmu, bertukar pikiran, dan juga merumuskan kreasi-kreasi ataupun kombinasi yang menarik untuk pengembangan dan kemajuan kelompok Jathilan Sekar Manunggal Mudho di Padukuhan Mendak.

\section{Simpulan}

Seringkali penelitian tentang interaksi simbolis mengkaji kebudayaan sebagai hasil dari cipta keluaran dari proses manipulasi manusia yang berorientasi pada kebutuhan hidup. Masyarakatlah yang pertama kali muncul lalu diikuti pemikiranpemikiran yang ada dalam masyarakat. Menganalisis perilaku dalam kelompok sosial dalam perilaku-perilaku individu yang menjadi bagian-bagian perilaku sosial dan obyek kajiannya berkecenderungan dengan masyarakat saat ini. Penelitian ini membahas bagaimana kesenian tradisional bernego dalam menghasilkan makna ketika menghadapi masyarakat yang memiliki keyakinan tertentu, dan memungkinkan saling menghargai.

Penelitian tentang interaksi simbolis masyarakat dalam memaknai kesenian Jathilan pada kelompok Jathilan Sekar Manunggal Mudho, Padukuhan Mendak, Desa Girisekar, Kecamatan Panggang, Kabupaten Gunung Kidul, dapat diambil kesimpulan bahwa :

1. Tindakan

Masyarakat menerima dengan baik kehadiran kesenian Jathilan di tengahtengah mereka karena membawa dampak positif bagi masyarakat. Kesenian Jathilan di Padukuhan Mendak juga mendapat dukungan dari pemerintah setempat. Wilayah RT 12 dan RT 13 Padukuhan Mendak dahulu terkenal sebagai daerah tertinggal, namun semenjak berdirinya kelompok kesenian Jathilan menjadi kegiatan positif untuk masyarakat dan kini daerah tersebut semakin maju.

\section{Gesture (Gerak Isyarat)}

Masyarakat memaknai adegan ndadi dari gerakan-gerakan penari Jathilan saat kerasukan roh halus. Kesenian Jathilan dahulu menyajikan alur cerita di setiap pertunjukannya dan jika pertunjukan tersebut hanya untuk hiburan, maka para 
pelaku kesenian Jathilan hanya berpurapura melakukan adegan ndadi. Sedangkan kesenian Jathilan di Padukuhan Mendak yang sekarang tidak menyajikan alur cerita karna murni untuk menghibur masyarakat.

\section{Simbol Signifikan}

Simbol-simbol yang terdapat dalam kesenian Jathilan yaitu terlihat dari unsurunsur kesenian Jathilan. Kesenian Jathilan dahulu adalah kesenian Jathilan klasik yang hanya menggunakan gendang untuk pengiringnya, sedangkan kesenian Jathilan di Padukuhan Mendak tergolong kesenian Jathilan modern karena menggunakan alat-alat musik modern dan lagu-lagu yang dibawakan mengikuti tren sekarang.

\section{Mind (Pikiran)}

Kesenian Jathilan di Padukuhan Mendak sangat identik dengan adegan ndadi yang disajikan saat pertunjukan. Masyarakat pada jaman dahulu menempatkan kesenian Jathilan sebagai ritual sakral. Masyarakat mempercayai jika kesenian tersebut tidak dipersembahkan dalam upacara adat maka akan menimbulkan bencana. Namun pada akhirnya fungsi hiburan lebih mendominasi aktivitas kesenian tersebut.

\section{Self(Diri)}

Para pelaku kesenian Jathilan sangat bertanggungjawab dan menerima segala konsekuensi ketika telah memutuskan bergabung dalam kelompok Jathilan Sekar Manunggal Mudho memposisikan dirinya sebagai anggota masyarakat dan menjalin komunikasi yang baik dengan masyarakat.

\section{Society (Masyarakat)}

Pihak internal kelompok Jathilan Sekar Manunggal Mudho selalu mengikutsertakan pihak keluarga dan masyarakat setempat dalam setiap pengambilan keputusan. Meskipun terdapat kelompok masyarakat yang pro dan kontra terhadap kesenian Jathilan, namun tidak menyebabkan perpecahan diantara masyarakat. Masyarakat Padukuhan Mendak selalu mengutamakan sikap saling menghargai. Interaksi simbolik masyarakat Padukuhan Mendak dalam memaknai kesenian Jathilan pada kelompok Jathilan Sekar Manunggal Mudho menunjukkan hasil bahwa fungsi kesenian Jathilan yang pada jaman dahulu digunakan untuk ritual, kini telah mengalami perubahan demi tuntutan kebutuhan pasar. Kesenian Jathilan di Padukuhan Mendak merupakan kesenian Jathilan modern dan memiliki nilai ekonomi bagi masyarakat. Beberapa simbol-simbol lama dari kesenian Jathilan mengalami pergeseran hingga kesenian Jathilan di Padukuhan Mendak berfungsi sebagai hiburan semata.

\section{Daftar Pustaka}

Bahasa dan Sastra. Universitas Negeri Semarang, Semarang

Mulyana, Dedy. (2008). Metode Penelitian Kualitatif. Bandung : PT. Remaja Rosdakarya

Kuswarsantyo. (2013). "Seni Jathilan: Bentuk, Fungsi Dan Perkembangannya (19862013)". Laporan Penelitian. Fakultas Bahasa dan Seni. Universitas Negeri Yogyakarta, Yogyakarta

Morissan. (2013). Teori Komunikasi Individu Hingga Massa. Jakarta: Kencana Prenada Media Group

Mulyana, Deddy. (2001). Metodologi Penelitian Kualitatif: Paradigma Baru Ilmu Komunikasi dan Ilmu Sosial Lainnya. Bandung: Remaja Rosdakarya 